\title{
Abundance and stratification of soil macroarthropods in a Caatinga Forest in Northeast Brazil
}

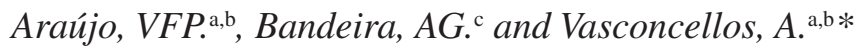 \\ aPrograma de Pós-graduação em Ciências Biológicas, Centro de Biociências, \\ Universidade Federal do Rio Grande do Norte - UFRN, CEP 59072-970, Natal, RN, Brazil \\ ${ }^{\text {b }}$ Departamento de Botânica, Ecologia e Zoologia, Centro de Biociências, \\ Universidade Federal do Rio Grande do Norte - UFRN, CEP 59072-970, Natal, RN, Brazil \\ ${ }^{\mathrm{c}}$ Departamento de Sistemática e Ecologia, Centro de Ciências Exatas e da Natureza, \\ Universidade Federal da Paraíba - UFPB, CEP 58051-900, João Pessoa, PB, Brazil \\ *e-mail: avasconcellos@cb.ufrn.br \\ Received November 10, 2009 - Accepted March 2, 2010 - Distributed October 31, 2010
}

(With 3 figures)

\begin{abstract}
In arid and semiarid environments, seasonality usually exerts a strong influence on the composition and dynamics of the soil community. The soil macroarthropods were studied in a Caatinga forest located in the Reserva Particular do Patrimônio Natural (RPPN) Fazenda Almas, São José dos Cordeiros, Paraíba, Brazil. Samples were collected during the dry and rainy seasons following the method proposed by the Tropical Soil Biology and Fertility Program (TSBF), with minor modifications. At each station, 15 soil blocks $(20 \times 20 \times 30 \mathrm{~cm}: 12 \mathrm{~L})$ were extracted and divided into three layers: A $(0-10 \mathrm{~cm}), \mathrm{B}(10-20 \mathrm{~cm})$, and C $(20-30 \mathrm{~cm})$. In the rainy and dry seasons $1,306 \pm 543(\mathrm{se})$ and $458 \pm 212 \mathrm{ind} \cdot \mathrm{m}^{-2}$ macroarthropods were found, respectively, with 35 and 18 respective taxa recorded. The abundance of individuals and taxa were significantly higher in the rainy season. Isoptera (57.8\%) was the most abundant taxon, followed by Hymenoptera: Formicidae (17.2\%), Coleoptera larvae (7.3\%), and Araneae (3.5\%). In the rainy season, abundance in layer A (576 \pm 138 ind. $\left.\mathrm{m}^{-2}\right)$ was significantly higher than that of layer C (117 \pm 64 ind. $\left.\mathrm{m}^{-2}\right)$, but was not different from layer B $\left(613 \pm 480\right.$ ind. $\left.\mathrm{m}^{-2}\right)$. There was also no difference between the layer B and C abundances. In the dry season, abundance in layer B (232 \pm 120 ind. $\left.\mathrm{m}^{-2}\right)$ was not significantly different compared to layer A (182 \pm 129 ind. $\left.\mathrm{m}^{-2}\right)$, but was significantly higher than abundance in layer C (44 \pm 35 ind. $\left.\mathrm{m}^{-2}\right)$. During the rainy season, layer A (34 taxa) was significantly richer in taxa than layers B (19 taxa) and C (11 taxa). On the other hand, during the dry season the richness of layers A (12 taxa) and B (12 taxa) was equal, but significantly higher than that of layer C (6 taxa). Richness of taxa and abundance were positively correlated with soil organic matter and negatively correlated with soil temperature. The community of soil macroarthropods in the area of Caatinga studied has taxonomic and functional structures that are relatively complex and is therefore likely to exert an influence on ecosystem productivity due to its physical effects on soil profile and necromass fragmentation, as occurs in other arid and semiarid ecosystems throughout the world.
\end{abstract}

Keywords: semiarid, soil fauna, environmental variables, insects.

\section{Abundância e estratificação de macroartrópodes de solo em uma Caatinga do Nordeste do Brasil}

\section{Resumo}

Em ambientes áridos e semiáridos, a sazonalidade geralmente exerce forte influência sobre a composição e dinâmica da comunidade do solo. A fauna de macroartrópodes de solo foi estudada em uma área de Caatinga arbórea, localizada na Reserva Particular do Patrimônio Natural (RPPN) Fazenda Almas, São José dos Cordeiros, Paraíba. As amostragens foram realizadas nas estações seca e chuvosa, seguindo o método proposto pelo Tropical Soil Biology and Fertility Program (TSBF), com pequenas modificações. Em cada estação foram extraídos 15 blocos de solo $(20 \times 20 \times 30 \mathrm{~cm}$ : $12 \mathrm{~L})$, divididos em três camadas: A $(0-10 \mathrm{~cm}), \mathrm{B}(10-20 \mathrm{~cm})$ e C $(20-30 \mathrm{~cm})$. Nas estações chuvosa e seca foram encontrados $1.306 \pm 543(e p)$ ind. $\mathrm{m}^{-2}$ e $458 \pm 212$ ind. $\mathrm{m}^{-2}$, com 35 e 18 táxons registrados, respectivamente. A abundância de indivíduos e a riqueza de táxons foram significativamente maiores na estação chuvosa. Isoptera (57,8\%) foi o táxon mais abundante, seguido por Hymenoptera: Formicidae (17,2 \%), larva de Coleoptera (7,3\%) e Araneae $(3,5 \%)$. Na estação chuvosa, a abundância da camada A $\left(576 \pm 138\right.$ ind. $\left.\mathrm{m}^{-2}\right)$ foi significativamente maior do que a da camada C (117 \pm 64 ind. $\left.\mathrm{m}^{-2}\right)$, mas não foi diferente da camada B (613 \pm 480 ind. $\left.\mathrm{m}^{-2}\right)$. Também não houve diferença entre as abundâncias das camadas B e C. Na estação seca, a abundância da camada B (232 \pm 120 ind.m $\left.{ }^{-2}\right)$ não apresentou 
diferença significativa em relação à camada $\mathrm{A}\left(182 \pm 129\right.$ ind. $\left.\mathrm{m}^{-2}\right)$, mas foi significativamente maior que a da camada C (44 \pm 35 ind. $\left.\mathrm{m}^{-2}\right)$. Na estação chuvosa, a camada A (34 táxons) foi significativamente mais rica em táxons do que as camadas B (19 táxons) e C (11 táxons). Por outro lado, na estação seca, a riqueza nas camadas A (12 táxons) e B (12 táxons) foi igual, mas significativamente maior do que a da C (6 táxons). A riqueza de táxons e a abundância foram relacionadas positivamente com a matéria orgânica e negativamente com a temperatura do solo. A comunidade de macroartrópodes de solo da Caatinga estudada possui estruturas taxonômicas e funcionais relativamente complexas e, por causa disso, é provável que exerça influência sobre a produtividade do ecossistema por sua ação física no perfil do solo e fragmentação da necromassa, como ocorre em outros ecossistemas áridos e semiáridos do mundo.

Palavras-chave: semiárido, fauna de solo, variáveis ambientais, insetos.

\section{Introduction}

Soil macroarthropods play an important role in most tropical terrestrial ecosystems, exerting a direct influence on the formation and stabilisation of soil structure and an indirect influence on the decomposition process, through strong participation in necromass fragmentation, and predation on the soil community (Lavelle et al., 1994; Decaëns et al., 2003). In addition, modification of soil structure by some macrofauna taxa known as ecosystem engineers, such as termites, earthworms and ants, can influence resource availability for organisms of other functional categories (Stork and Eggleton, 1992; Lavelle, 1997; Jouquet et al., 2006).

Macroarthropod distribution patterns are related to temperature and humidity gradients, especially in savanna ecosystems, which display marked seasonality, with well-defined dry and rainy seasons (Lavelle, 1983; Vasconcellos et al., 2010a). However, several studies have shown a lack of correlation between soil abiotic factors and spatial distribution of various taxa of invertebrates (Rossi et al., 1997; Ettema et al., 1998).

Despite their crucial role in ecosystem function, soil communities have been little studied in some neotropical ecosystems, such as the Caatinga and the Atlantic Forest (Silva and Bandeira, 1999; Souto et al., 2008). The Caatinga spans an area of about $800,000 \mathrm{~km}^{2}$ and covers most of Brazil's Northeast (Andrade-Lima, 1981; Prado, 2003). It is characterised by high temperatures and high potential evapotranspiration, which exacerbates the effects of irregularity and low rainfall indices (Andrade-Lima, 1981; Coutinho, 2006). The region's landscape is dominated by a mosaic of physiognomic forms such as arboreal, shrubby, and thorny caatinga, all adapted to drought (Coimbra-Filho and Câmara, 1996). The Caatinga has been severely altered by firewood cutting, agriculture, fires, hunting, and continuous movement of cattle and sheep herds, leaving only a few areas with primary vegetation (Santos and Tabarelli, 2002; Leal et al., 2005).

This study aims to analyse the abundance and stratification of the soil macroarthropod community in dry and rainy seasons in a Caatinga forest located between the Northern Sertaneja Depression and Borborema Plateau Ecoregions (sensu Velloso et al., 2002). In addition, macroarthropod abundance and distribution at a soil depth of $30 \mathrm{~cm}$ were related to temperature, moisture content, and soil organic matter.

\section{Material and Methods}

The study sites are located in the Reserva Particular do Patrimônio Natural (RPPN) Fazenda Almas, São José dos Cordeiros, a private and protected area located in the state of Paraíba, Brazil ( $07^{\circ} 28^{\prime} \mathrm{S}$ and $\left.36^{\circ} 52^{\prime} \mathrm{W}\right)$. Fazenda Almas encompasses 3,505 ha of caatinga vegetation at altitudes ranging from 600 to $720 \mathrm{~m}$ a.s.l. Average annual precipitation, temperature, and humidity are $560 \pm 230 \mathrm{~mm}$ $(s d), 25^{\circ} \mathrm{C}$, and $65 \%$, respectively (Paraíba, 1985). Rainfall is concentrated between February and May.

Soil macroarthropods were collected in dense caatinga vegetation in May 2007 and November 2008, during the rainy and dry seasons, respectively. For the samples, two parallel transects of $100 \mathrm{~m}, 30 \mathrm{~m}$ apart, were established near the centre of the largest section of caatinga in the RPPN-Fazenda Almas. Fifteen collection points were established along these transects, with at least $10 \mathrm{~m}$ between any two points. The macroarthropods were collected using the method proposed by the Tropical Soil Biology and Fertility Program (TSBF) (Anderson and Ingram, 1993), modified by Silva and Bandeira (1999). At each station, 15 soil blocks $(20 \times 20 \times 30 \mathrm{~cm}: 12 \mathrm{~L})$ were collected extracted and divided into three layers: A $(0-10 \mathrm{~cm}), \mathrm{B}(10-20 \mathrm{~cm})$, and C $(20-30 \mathrm{~cm})$, for a total of 45 samples per season. Litter was included in layer A as it was very fine or absent at most points. The soil of each layer was separated into plastic trays, with the animals manually collected in properly labelled bottles with $75 \%$ alcohol. In the laboratory, the material was sorted and identified at the order, family, and/or subfamily level. For identification, specialised bibliographies were consulted (Borror and Delong, 1988; Dindal, 1990). The material was placed in the Entomology Laboratory collection at the Universidade Federal da Paraíba. The collections were aimed toward arthropods that could be seen and captured by hand, leaving out organisms with a body size of less than $2 \mathrm{~mm}$, such as Acari and Collembola.

The temperature of each soil layer was measured directly in the field using a mercury thermometer. Soil samples were taken to measure the availability of soil organic matter (SOM) and moisture content in the laboratory. Moisture content and organic matter were determined through gravimetric and loss-on-ignition methods, respectively, described by Allen et al. (1974) and modified by Silva and Bandeira (1999). 
The Spearman correlation was used to assess the relationships between environmental factors (soil temperature, organic matter, and moisture content) and the abundance of individuals and taxa richness, understood as the number of taxonomic units (Class, Order, or Family). The Mann-Whitney $\mathrm{U}$ test was performed to compare taxa richness and abundance in the dry and rainy seasons. Abundance and richness variability among the soil layers was compared through non-parametric analysis of variance (Kruskal-Wallis), using Dunn's test a posteriori. The non-parametric tests were used because the data did not show normal distribution and homogeneity of variance. These tests were conducted using STATISTIC 5.0 software (StatSoft, 1995).

\section{Results}

Overall, 1,306 \pm 543 (se) macroarthropods. $\mathrm{m}^{-2}$ were found in the rainy season and $458 \pm 212$ macroarthropods. $\mathrm{m}^{-2}$ were found in the dry season, pertaining to 35 and 18 taxa, respectively (Table 1). Abundance (Mann-Whitney $U=514.5$; $\mathrm{Z}=4.02 ; \mathrm{n}=45 ; \mathrm{p}<0.001$ ) and taxa richness (Mann-Whitney $\mathrm{U}=434.0 ; \mathrm{Z}=4.67 ; \mathrm{n}=45 ; \mathrm{p}<0.001)$ were significantly higher in the rainy season.

In the rainy season, abundance $\left(576 \pm 138\right.$ ind. $\left.\mathrm{m}^{-2}\right)$ in layer A was significantly higher than that of layer C $\left(117 \pm 64\right.$ ind. $\left.\mathrm{m}^{-2}\right)$, but was not different from layer B $\left(613 \pm 480\right.$ ind. $\left.\mathrm{m}^{-2}\right)\left(\mathrm{H}_{\text {rainy }}=16.46 ;\right.$ d.f. $\left.=2 ; \mathrm{n}=45 ; \mathrm{p}<0.001\right)$. There was also no difference between the layer B and C abundances (Figure 1). In the dry season, abundance in layer B $\left(232 \pm 120\right.$ ind. $\left.\mathrm{m}^{-2}\right)$ was not significantly different compared to layer A $\left(182 \pm 129\right.$ ind $\left.\mathrm{m}^{-2}\right)$, but was significantly higher than abundance in layer $\mathrm{C}\left(44 \pm 35\right.$ ind. $\left.\mathrm{m}^{-2}\right)\left(\mathrm{H}_{\mathrm{dry}}=13.98\right.$; d.f. $=2 ; \mathrm{n}=45 ; \mathrm{p}<0.001)$ (Figure 1$)$.

The soil macrofauna was largely dominated by insects, which made up approximately $90 \%$ of all individuals sampled. Isoptera was the most abundant taxon, regardless of layer or season, representing $57.8 \%$ of the abundance of arthropods found, followed by Hymenoptera (Formicidae)
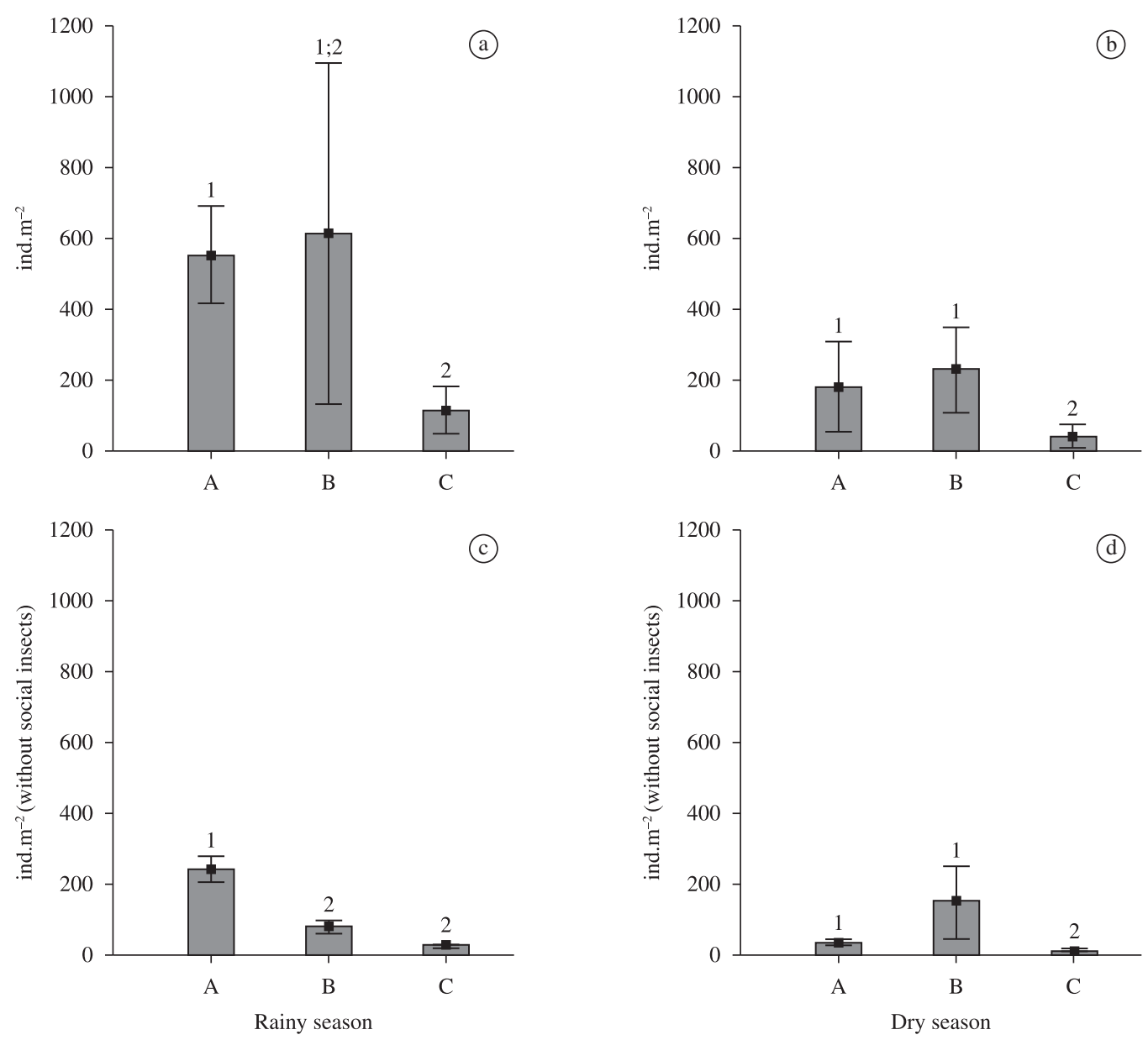

Figure 1. Abundance of the edaphic macroarthropods in the soil layers ( $\mathrm{A}=0$ to $10 \mathrm{~cm}, \mathrm{~B}=10$ to $20 \mathrm{~cm}, \mathrm{C}=20$ to $30 \mathrm{~cm}$ ) in rainy and dry seasons in the RPPN-Fazenda Almas, São José dos Cordeiros, Paraíba, Brazil. a) total abundance during the rainy season; b) total abundance during the dry season; c) abundance with the exception of Formicidae and Isoptera during the rainy season; and d) abundance with the exception of Formicidae and Isoptera during the dry season. (• mean, $\perp$ std error). The numbers 1 and 2 refer to the results of Dunn's test, which indicates difference between the soil layers. 
Table 1. Abundance (Ind. $\mathrm{m}^{-2}$ ) and percentage (\%) of different soil arthropod groups in the Caatinga of the RPPN-Fazenda Almas, São José dos Cordeiros, Paraíba, Brazil.

\begin{tabular}{|c|c|c|c|c|c|c|c|c|c|c|}
\hline \multirow{2}{*}{\multicolumn{3}{|c|}{$\begin{array}{c}\text { Edaphic } \\
\text { Arthropod }\end{array}$}} & \multicolumn{8}{|c|}{ Rainy } \\
\hline & & & \multicolumn{2}{|c|}{$0-10 \mathrm{~cm}$} & \multicolumn{2}{|c|}{$10-20 \mathrm{~cm}$} & \multicolumn{2}{|c|}{$20-30 \mathrm{~cm}$} & \multicolumn{2}{|c|}{ Total } \\
\hline & & & Ind.m-2 & $\%$ & Ind.m ${ }^{-2}$ & $\%$ & Ind.m ${ }^{-2}$ & $\%$ & Ind.m ${ }^{-2}$ & $\%$ \\
\hline \multirow[t]{4}{*}{ Arachnida } & Araneae & Araneomorphae & 18 & 3.1 & 7 & 1.1 & 2 & 1.7 & 27 & 2.1 \\
\hline & & Mygalomorphae & 15 & 2.6 & 0 & 0.0 & 0 & 0.0 & 15 & 1.2 \\
\hline & Scorpionida & & 0 & 0.0 & 0 & 0.0 & 0 & 0.0 & 0 & 0.0 \\
\hline & Pseudoscorpio & & 0 & 0.0 & 0 & 0.0 & 0 & 0.0 & 0 & 0.0 \\
\hline \multirow[t]{6}{*}{ Myriapoda } & Symphyla & & 2 & 0.3 & 12 & 2.0 & 8 & 6.8 & 22 & 1.7 \\
\hline & Geophilomorp & & 17 & 3.0 & 2 & 0.3 & 0 & 0.0 & 19 & 1.5 \\
\hline & Scolopendrom & & 8 & 1.4 & 2 & 0.3 & 5 & 4.3 & 15 & 1.2 \\
\hline & Spirobolida & & 5 & 0.9 & 0 & 0.0 & 2 & 1.7 & 7 & 0.5 \\
\hline & Spirobolida (in & ure) & 17 & 3.0 & 3 & 0.5 & 0 & 0.0 & 20 & 1.5 \\
\hline & Polydesmida & & 2 & 0.3 & 0 & 0.0 & 0 & 0.0 & 2 & 0.2 \\
\hline Crustacea & Isopoda & & 3 & 0.5 & 0 & 0.0 & 0 & 0.0 & 3 & 0.2 \\
\hline \multirow[t]{2}{*}{ Hexapoda } & Diplura & Japygidae & 5 & 0.9 & 5 & 0.8 & 2 & 1.7 & 12 & 0.9 \\
\hline & & Projapygidae & 5 & 0.9 & 0 & 0.0 & 0 & 0.0 & 5 & 0.4 \\
\hline \multirow[t]{24}{*}{ Insecta } & Archeognatha & rocoryphia) & 2 & 0.3 & 2 & 0.3 & 0 & 0.0 & 4 & 0.3 \\
\hline & Thysanura & Lepismatidae & 3 & 0.5 & 0 & 0.0 & 0 & 0.0 & 3 & 0.2 \\
\hline & Blattodea & Blatellidae & 7 & 1.2 & 3 & 0.5 & 0 & 0.0 & 10 & 0.8 \\
\hline & Isoptera & Indeterminado & 12 & 2.1 & 0 & 0.0 & 0 & 0.0 & 12 & 0.9 \\
\hline & & Termitidae & & & & & & & & \\
\hline & & Apicotermitinae & 22 & 3.8 & 12 & 2.0 & 38 & 32.5 & 72 & 5.5 \\
\hline & & Nasutitermitinae & 7 & 1.2 & 0 & 0.0 & 0 & 0.0 & 7 & 0.5 \\
\hline & & Termitinae & 7 & 1.2 & 483 & 78.8 & 12 & 10.3 & 502 & 38.6 \\
\hline & & Rhinotermitidae & 112 & 19.4 & 20 & 3.3 & 37 & 31.6 & 169 & 13.0 \\
\hline & Orthoptera & Gryllidae & 17 & 3.0 & 2 & 0.3 & 0 & 0.0 & 19 & 1.5 \\
\hline & $\begin{array}{l}\text { Hemiptera } \\
\text { (immature) }\end{array}$ & & 3 & 0.5 & 2 & 0.3 & 2 & 1.7 & 7 & 0.5 \\
\hline & & $\begin{array}{l}\text { Cicadidae } \\
\text { (immature) }\end{array}$ & 2 & 0.3 & 2 & 0.3 & 0 & 0.0 & 4 & 0.3 \\
\hline & Coleoptera & Staphylinidae & 2 & 0.3 & 0 & 0.0 & 0 & 0.0 & 2 & 0.2 \\
\hline & & Rhizophagidae & 3 & 0.5 & 0 & 0.0 & 0 & 0.0 & 3 & 0.2 \\
\hline & & Carabidae & 2 & 0.3 & 0 & 0.0 & 0 & 0.0 & 2 & 0.2 \\
\hline & $\begin{array}{l}\text { Coleoptera } \\
\text { (immature) }\end{array}$ & & 80 & 13.9 & 23 & 3.8 & 2 & 1.7 & 105 & 8.1 \\
\hline & Diptera & Cecidomyiidae & 0 & 0.0 & 5 & 0.8 & 0 & 0.0 & 5 & 0.4 \\
\hline & & Syrphidae & 2 & 0.3 & 0 & 0.0 & 0 & 0.0 & 2 & 0.2 \\
\hline & Diptera (imma & & 17 & 3.0 & 0 & 0.0 & 0 & 0.0 & 17 & 1.3 \\
\hline & Lepidoptera & & 13 & 2.3 & 2 & 0.3 & 0 & 0.0 & 15 & 1.2 \\
\hline & Lepidoptera ( & & 2 & 0.3 & 0 & 0.0 & 0 & 0.0 & 2 & 0.2 \\
\hline & Hymenoptera & Formicidae & 158 & 27.4 & 18 & 2.9 & 7 & 6.0 & 183 & 14.1 \\
\hline & & $\begin{array}{l}\text { Formicidae } \\
\text { (immature) }\end{array}$ & 2 & 0.3 & 0 & 0.0 & 0 & 0.0 & 2 & 0.2 \\
\hline & Hymenoptera & & 2 & 0.3 & 0 & 0.0 & 0 & 0.0 & 2 & 0.2 \\
\hline \multicolumn{3}{|c|}{ Undetermined } & 2 & 0.3 & 8 & 1.3 & 0 & 0.0 & 10 & 0.8 \\
\hline \multicolumn{3}{|c|}{ Total } & 576 & 100 & 613 & 100 & 117 & 100 & 1306 & 100 \\
\hline
\end{tabular}


Table 1. Continued ...

\begin{tabular}{|c|c|c|c|c|c|c|c|c|c|c|}
\hline \multicolumn{3}{|c|}{ Edaphic Arthropod } & \multicolumn{8}{|c|}{ Dry } \\
\hline & & & \multicolumn{2}{|c|}{$0-10 \mathrm{~cm}$} & \multicolumn{2}{|c|}{$10-20 \mathrm{~cm}$} & \multicolumn{2}{|c|}{$20-30 \mathrm{~cm}$} & \multicolumn{2}{|c|}{ Total } \\
\hline & & & Ind.m ${ }^{-2}$ & $\%$ & Ind. $\mathrm{m}^{-2}$ & $\%$ & Ind. $^{-2}$ & $\%$ & Ind.m ${ }^{-2}$ & $\%$ \\
\hline \multirow[t]{4}{*}{ Arachnida } & Araneae & Araneomorphae & 8 & 4.4 & 3 & 1.3 & 2 & 4.5 & 13 & 2.9 \\
\hline & & Mygalomorphae & 5 & 2.7 & 2 & 0.9 & 0 & 0.0 & 7 & 1.5 \\
\hline & Scorpionida & & 2 & 1.1 & 0 & 0.0 & 0 & 0.0 & 2 & 0.4 \\
\hline & Pseudoscorpionida & & 0 & 0.0 & 3 & 1.3 & 0 & 0.0 & 3 & 0.7 \\
\hline \multirow[t]{6}{*}{ Myriapoda } & Symphyla & & 0 & 0.0 & 2 & 0.9 & 0 & 0.0 & 2 & 0.4 \\
\hline & Geophilomorpha & & 0 & 0.0 & 0 & 0.0 & 0 & 0.0 & 0 & 0.0 \\
\hline & Scolopendromorpha & & 2 & 1.1 & 0 & 0.0 & 0 & 0.0 & 2 & 0.4 \\
\hline & Spirobolida & & 0 & 0.0 & 2 & 0.9 & 0 & 0.0 & 2 & 0.4 \\
\hline & Spirobolida (immatu & & 3 & 1.6 & 0 & 0.0 & 0 & 0.0 & 3 & 0.7 \\
\hline & Polydesmida & & 0 & 0.0 & 0 & 0.0 & 0 & 0.0 & 0 & 0.0 \\
\hline Crustacea & Isopoda & & 0 & 0.0 & 0 & 0.0 & 0 & 0.0 & 0 & 0.0 \\
\hline \multirow[t]{2}{*}{ Hexapoda } & Diplura & Japygidae & 0 & 0.0 & 0 & 0.0 & 0 & 0.0 & 0 & 0.0 \\
\hline & & Projapygidae & 0 & 0.0 & 0 & 0.0 & 0 & 0.0 & 0 & 0.0 \\
\hline \multirow[t]{24}{*}{ Insecta } & Archeognatha (Micr & coryphia) & 0 & 0.0 & 2 & 0.9 & 3 & 6.8 & 5 & 1.1 \\
\hline & Thysanura & Lepismatidae & 3 & 1.6 & 0 & 0.0 & 0 & 0.0 & 3 & 0.7 \\
\hline & Blattodea & Blatellidae & 0 & 0.0 & 0 & 0.0 & 0 & 0.0 & 0 & 0.0 \\
\hline & Isoptera & Indeterminado & 0 & 0.0 & 5 & 2.2 & 7 & 15.9 & 12 & 2.6 \\
\hline & & Termitidae & & & & & & & & \\
\hline & & Apicotermitinae & 0 & 0.0 & 0 & 0.0 & 0 & 0.0 & 0 & 0.0 \\
\hline & & Nasutitermitinae & 10 & 5.5 & 7 & 3.0 & 0 & 0.0 & 17 & 3.7 \\
\hline & & Termitinae & 132 & 72.5 & 70 & 30.2 & 0 & 0.0 & 202 & 44.3 \\
\hline & & Rhinotermitidae & 0 & 0.0 & 0 & 0.0 & 27 & 61.4 & 27 & 5.9 \\
\hline & Orthoptera & Gryllidae & 0 & 0.0 & 0 & 0.0 & 0 & 0.0 & 0 & 0.0 \\
\hline & $\begin{array}{l}\text { Hemiptera } \\
\text { (immature) }\end{array}$ & & 0 & 0.0 & 0 & 0.0 & 0 & 0.0 & 0 & 0.0 \\
\hline & & $\begin{array}{l}\text { Cicadidae } \\
\text { (immature) }\end{array}$ & 0 & 0.0 & 0 & 0.0 & 0 & 0.0 & 0 & 0.0 \\
\hline & Coleoptera & Staphylinidae & 0 & 0.0 & 0 & 0.0 & 0 & 0.0 & 0 & 0.0 \\
\hline & & Rhizophagidae & 0 & 0.0 & 0 & 0.0 & 0 & 0.0 & 0 & 0.0 \\
\hline & & Carabidae & 2 & 1.1 & 0 & 0.0 & 0 & 0.0 & 2 & 0.4 \\
\hline & $\begin{array}{l}\text { Coleoptera } \\
\text { (immature) }\end{array}$ & & 7 & 3.8 & 17 & 7.3 & 0 & 0.0 & 24 & 5.3 \\
\hline & Diptera & Cecidomyiidae & 0 & 0.0 & 0 & 0.0 & 0 & 0.0 & 0 & 0.0 \\
\hline & & Syrphidae & 0 & 0.0 & 0 & 0.0 & 0 & 0.0 & 0 & 0.0 \\
\hline & Diptera (immature) & & 5 & 2.7 & 7 & 3.0 & 2 & 4.5 & 14 & 3.1 \\
\hline & Lepidoptera & & 0 & 0.0 & 0 & 0.0 & 0 & 0.0 & 0 & 0.0 \\
\hline & Lepidoptera (pupa) & & 0 & 0.0 & 0 & 0.0 & 0 & 0.0 & 0 & 0.0 \\
\hline & Hymenoptera & Formicidae & 3 & 1.6 & 112 & 48.3 & 3 & 6.8 & 118 & 25.9 \\
\hline & & $\begin{array}{l}\text { Formicidae } \\
\text { (immature) }\end{array}$ & 0 & 0.0 & 0 & 0.0 & 0 & 0.0 & 0 & 0.0 \\
\hline & Hymenoptera & & 0 & 0.0 & 0 & 0.0 & 0 & 0.0 & 0 & 0.0 \\
\hline \multicolumn{3}{|c|}{ Undetermined } & 0 & 0.0 & 0 & 0.0 & 0 & 0.0 & 0 & 0.0 \\
\hline \multicolumn{3}{|c|}{ Total } & 182 & 100 & 232 & 100 & 44 & 100 & 458 & 100 \\
\hline
\end{tabular}


with $17.2 \%$, Coleoptera larvae (7.3\%), and Araneae (3.5\%). The abundance of most taxa varied according to soil depth and season (Figure 2).

Social insects (Isoptera and Formicidae) accounted for more than $70 \%$ of the fauna, both in the rainy and dry seasons. Termitidae was the dominant family of Isoptera, accounting $44.6 \%$ of the soil fauna in the rainy season and
$48.0 \%$ in the dry season, while Rhinotermitidae accounted only 13.0 and $5.9 \%$, respectively. Termitinae was the dominant subfamily of Termitidae, being well sampled in both seasons. On the other hand, Apicotermitinae (Termitidae) was sampled only in the rainy season, while Nasutitermitinae (Termitidae) occurred mainly in the dry season (Table 1).

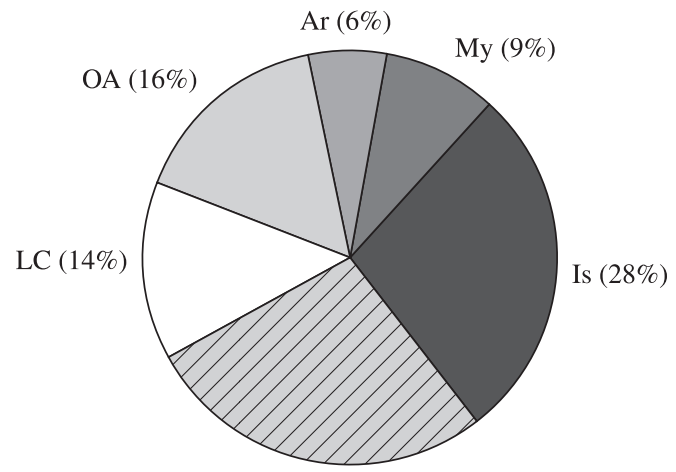

Fo $(28 \%)$

Rainy period - A

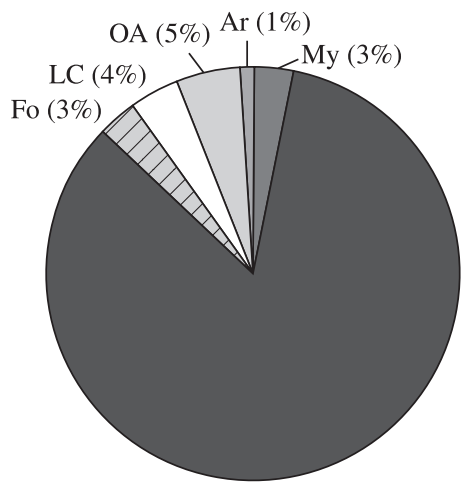

Is $(84 \%)$

Rainy period - B

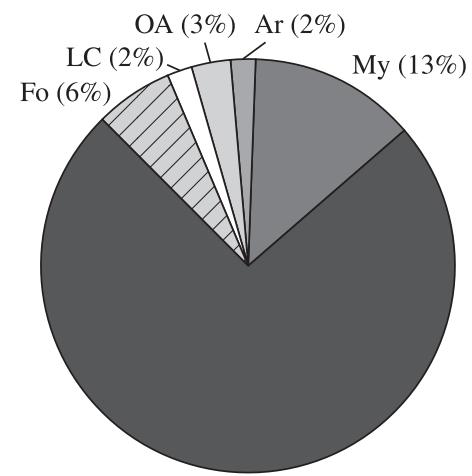

Is $(74 \%)$

Rainy period - C

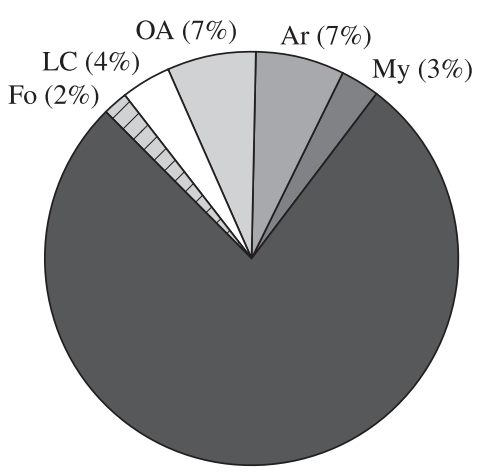

Is $(77 \%)$

Dry period - A

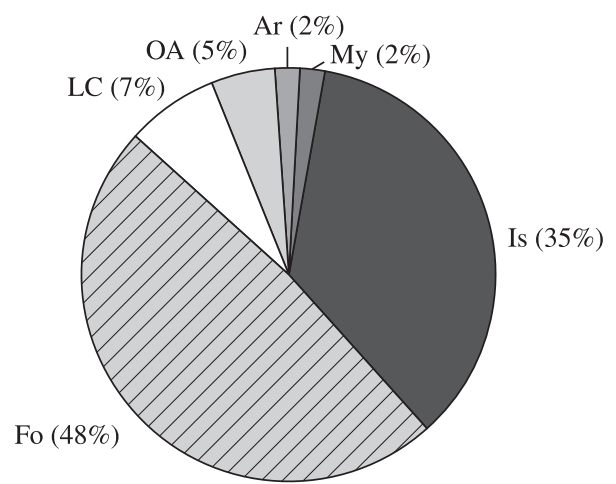

Dry period - B

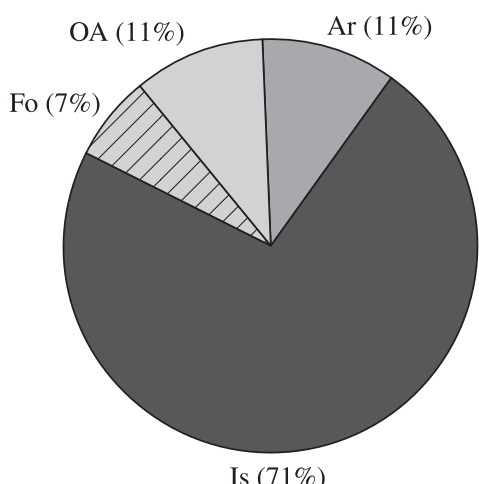

Dry period - C

Figure 2. Percentage of edaphic macroarthropods in the soil layers $(A=0$ to $10 \mathrm{~cm}, \mathrm{~B}=10$ to $20 \mathrm{~cm}, \mathrm{C}=20$ to $30 \mathrm{~cm})$ in rainy and dry seasons in the RPPN-Fazenda Almas, São José dos Cordeiros, Paraíba, Brazil. Is = Isoptera, Fo = Formicidae, Coleoptera Larvae, $\mathrm{OA}=$ Other Arthropods, $\mathrm{Ar}=$ Araneae, $\mathrm{My}=$ Myriapoda . 
Excluding social insects from the analyses, it was found that in the rainy season layer A abundance $\left(256 \pm 34\right.$ ind. $\left.\mathrm{m}^{-2}\right)$ was significantly higher than layer B $\left(80 \pm 18\right.$ ind. $\left.\mathrm{m}^{-2}\right)$ and C $\left(23 \pm 7\right.$ ind $\left.\mathrm{m}^{-2}\right)$ abundances, and that layers $\mathrm{B}$ and $\mathrm{C}$ were not significantly different $\left(\mathrm{H}_{\text {rainy }}=16.46\right.$; d.f. $=2 ; \mathrm{n}=45$; $\mathrm{p}<0.001$ ) (Figure 1). In the dry season, abundances in layers A $\left(37 \pm 10\right.$ ind. $\left.\mathrm{m}^{-2}\right)$ and B $\left(38 \pm 11\right.$ ind. $\left.\mathrm{m}^{-2}\right)$ showed no significant difference, but both differ from layer $\mathrm{C}$ $\left(7 \pm 7\right.$ ind. $\left.\mathrm{m}^{-2}\right)\left(\mathrm{H}_{\text {dry }}=13.30 ;\right.$ d.f. $\left.=2 ; \mathrm{n}=45 ; \mathrm{p}<0.001\right)$ (Figure 1). In the rainy season, layer A, with 34 taxa, displayed significantly greater richness than layers B (19 taxa) and $\mathrm{C}\left(11\right.$ taxa) $\left(\mathrm{H}_{\text {rainy }}=24.40\right.$; d.f. $=2 ; \mathrm{n}=45$; $\mathrm{p}<0.001$ ) (Figure 3 ). In the dry season, the richness of layer A (12 taxa) and of layer B (12 taxa) did not differ but were significantly higher than that of layer $\mathrm{C}$ (6 taxa) $\left(\mathrm{H}_{\text {dry }}=15.63 ;\right.$ d.f. $\left.=2 ; \mathrm{n}=45 ; \mathrm{p}<0.001\right)$ (Figure 3$)$.

The richness of macroarthropods was positively correlated with organic matter $\left(r_{s}=0.42 ; n=90 ; p<0.001\right)$ and soil moisture content $\left(r_{s}=0.27 ; n=90 ; p<0.050\right)$ and negatively correlated with soil temperature $\left(r_{s}=-0.39\right.$; $\mathrm{n}=90 ; \mathrm{p}<0.001$ ) (Table 2). Macroarthropod abundance also displayed a negative correlation with soil temperature $\left(\mathrm{r}_{\mathrm{s}}=-0.35 ; \mathrm{n}=90 ; \mathrm{p}<0.001\right)$ and a positive correlation with organic matter $\left(r_{s}=0.33 ; n=90 ; p<0.001\right)$ but the relationship to soil moisture content was only marginally significant $\left(r_{s}=0.20 ; n=90 ; p=0.06\right)$.

\section{Discussion}

The recorded taxa richness and abundance in the soil macroarthropod community fell within the range noted for other savanna environments in the Neotropical region, such as the Brazilian Cerrado (Silva et al., 2006; Aquino et al., 2008). The macrofauna richness of the Cerrado varies from 15 to 21 taxonomic units (Class, Order, or Family) (Aquino et al., 2008). Silva et al. (2006) estimated an abundance of between 484 to 3,106 ind. $\mathrm{m}^{-2}$ to a depth of $30 \mathrm{~cm}$ in different production systems of the Cerrado. Decaëns et al. (1994) recorded 2,830 to 4,293 ind. $\mathrm{m}^{-2}$ for the Llanos in Colombia.

The difference in the pattern of macroarthropod richness and abundance between the rainy and dry seasons may be related to seasonal variation in some climatic elements of the Caatinga, such as rainfall and temperature, keeping in mind the effects of these factors on resource availability (e.g., organic matter), composition, and community dynamics (Mooney, 1981; Doblas-Miranda et al., 2007; Hernandéz, 2007; Vasconcellos et al., 2010a). On a regional
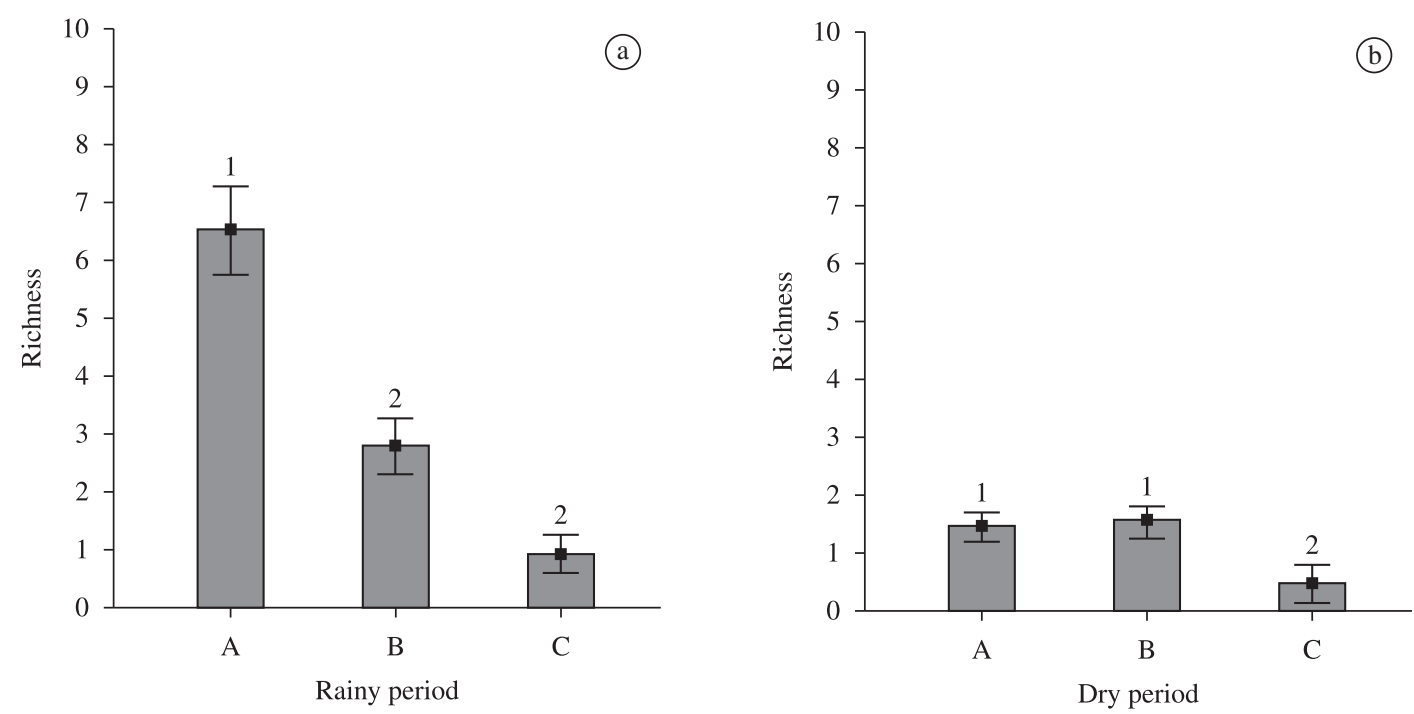

Figure 3. Richness of edaphic macroarthropods in the soil layers $(A=0$ to $10 \mathrm{~cm}, \mathrm{~B}=10$ to $20 \mathrm{~cm}, \mathrm{C}=20$ to $30 \mathrm{~cm})$ in rainy (a) and dry (b) seasons in the RPPN-Fazenda Almas, São José dos Cordeiros, Paraíba, Brazil. (• mean, + std error). The numbers 1 and 2 refer to the results of Dunn's test, which indicates difference between the soil layers.

Table 2. Soil abiotic factors in a Caatinga Forest in Northeast Brazil.

\begin{tabular}{lccccc}
\hline \multirow{2}{*}{$\begin{array}{c}\text { Abiotic } \\
\text { factors }\end{array}$} & \multicolumn{3}{c}{ Rainy } & \multicolumn{2}{c}{ Seasons } \\
\cline { 2 - 3 } \cline { 2 - 3 } & $($ mean $\pm \mathbf{~ s e * )}$ & range & & Dry \\
\hline Moisture $(\%)$ & $3.3 \pm 1.2$ & $1.6-19.1$ & & $1.3 \pm 0.4$ & range \\
Organic Matter $(\mathrm{g})$ & $2.1 \pm 0.1$ & $0.7-5.0$ & & $1.6 \pm 0.1$ & $0-18.2$ \\
Temperature $\left({ }^{\circ} \mathrm{C}\right)$ & $22.2 \pm 0.1$ & $21.0-23.0$ & & $28.3 \pm 0.2$ & $4.6-1.0$ \\
\hline
\end{tabular}

$*_{\text {se }}=$ standard error 
scale, precipitation and temperature are the most important climatic elements in the control of ecological processes and are related to litter production and decomposition (Valenti et al., 2008). In the same area of this study it was confirmed that precipitation and relative humidity were the main predictors of the abundance of insects collected with malaise and pitfall traps and beating trays over a 24-month period (Vasconcellos et al., 2010b).

Social insects were the main representatives of macroarthropods between 10 and $20 \mathrm{~cm}$, but excluding these, a greater number of individuals were found in the 0-10 cm layer. According to Peterson and Luxton (1982) it is accepted that most soil biota is generally found between 0 and $10 \mathrm{~cm}$. Benito et al. (2004) showed that approximately $80 \%$ of macroinvertebrates in the Cerrado are concentrated up to a depth of $10 \mathrm{~cm}$. However, this trend varies considerably according to the ecosystem and taxa involved (Walwork, 1970; Adis et al., 1989; Dindal, 1990; Harada and Bandeira, 1994).

Macroarthropod abundance in the soil's outermost layer was more related to temperature and SOM. Despite the marginal relationship abundance has with soil moisture, this abiotic variable is crucial for increasing the biomass of soil microorganisms, which can stimulate the activity of predatory and saprophagous arthropods that make up the soil micro-, meso-, and macrofauna (Swift et al., 1979; Lavelle et al., 1995). According to Jiménez et al. (2001), the spatial distribution of soil fauna is partly influenced by abiotic factors.

In terms of the number of individuals, Isoptera were dominant in most layers, both in the rainy and dry seasons. Most species of Apicotermitinae and many species of Termitinae and Nasutitermitinae have convergently specialised in the use of mineral soil mixed with organic matter in various stages of decomposition (Lima and Costa-Leonardo, 2007). The soil-eating Isoptera play an important role in decomposition processes and energy flow in tropical ecosystems (Wood et al., 1982; Eggleton et al. 1996; Bandeira and Vasconcellos, 2002).

The second most abundant group was Formicidae, with the largest number of individuals between 0 and $10 \mathrm{~cm}$ in the rainy season and between 10 and $20 \mathrm{~cm}$ in the dry season. Doblas-Miranda et al. (2007) found that Hymenoptera, especially ants, were the most abundant macroinvertebrates in an arid ecosystem of the Mediterranean. Social insects (termites and ants) can apparently have a strong influence on the Caatinga soil, altering its porosity and water retention ability, as occurs in other arid and semi-arid ecosystems of the world, such as the Chihuahuan Desert, African Karoo Desert, the desert in Israel, and the Australian semiarid ecosystem (Whitford, 1996; Vasconcellos et al., 2010b). These groups also dominate the soil macrofauna of other areas of Neotropical savanna, such as the Colombian Llanos (Decaëns et al., 1994) and the Cerrado (Aquino et al., 2008).

Adequate knowledge of soil biodiversity and its functionality can provide essential information for proper soil management, aiming to maintain or increase the productivity of the Caatinga. The Caatinga soil macroarthropod community studied has relatively complex taxonomic and functional structures, as it is influenced by the seasonality of climatic elements and their effects on the availability of resources arising from necromass decomposition. Moreover, the diversity of taxa found suggests that these organisms may eventually influence ecosystem productivity due to their effects on the soil profile, redistribution of organic material and necromass fragmentation, as has been proven in other arid and semiarid ecosystems of the world.

Acknowledgements - The authors are grateful to the Braz family, owners of the RPPN-Fazenda Almas, for logistical support during the research, and to José Wellington de Morais and Ricardo Andreazze for their valuable input. The authors thank to Aline Oliveira Lopes, Nicholas Araújo, and Uirandé Oliveira for their help during the field work. We are also grateful to CAPES/UFRN, for the scholarship granted to Virgínia F. P. de Araújo. This research was supported by CNPq/PELD (520062/2006-0).

\section{References}

ADIS, J., RIBEIRO, EF., MORAIS, JW. and CAVALCANTE, ETS., 1989. Vertical distribution and abundance of Arthropods from white sand soil of a Neotropical Campinarana Forest during the dry season. Studies on Neotropical Fauna and Environment, vol. 24, p. 201-211.

ALLEN, SE., GRISHALL, HM., PARKINSON, JA. and QUARNBY, C., 1974. Analysis of soil. In ALLEN, SE., (ed.). Chemical Analysis of ecological materials. London: Blackwell Scientific Publications. $650 \mathrm{p}$.

ANDERSON, JM. and INGRAM, JSM., 1993. Tropical soil biology and fertility: a Handbook of Methods. 2 ed. Wallingford: CAB International. $77 \mathrm{p}$.

ANDRADE-LIMA, D., 1981. The caatingas dominium. Revista Brasileira de Botânica, vol. 4, no. 2, p. 149-153.

AQUINO, AM., CORREIA, MEF. and ALVES, MV., 2008. Diversidade de Macrofauna Edáfica no Brasil. In MOREIRA, FMS., SIQUEIRA, JO. and BRUSSAARD, L., (eds.). Biodiversidade do solo em ecossistemas brasileiros. Lavras: Editora UFLA. p. 143-170.

BANDEIRA, AG. and VASCONCELLOS, A., 2002. A quantitative survey of termites in a gradient of disturbed highland forest in Northeastern Brazil. Sociobiology, vol. 39, no. 3, p. 429-439.

BENITO, NP., BROSSARD, M., PASINI, A., GUIMARÃES, MF. and BOBILLIER, B., 2004. Transformations of soil macroinvertebrate populations after native vegetation conversion to pasture cultivation (Brazilian Cerrado). European Journal of Soil Biology, vol. 40, p. $147-154$

BORROR, DJ. and DELONG, DM., 1988. Introdução ao estudo dos insetos. São Paulo: Edgar Blücker Ltda. 653 p.

COIMBRA-FILHO, AF. and CÂMARA, IG., 1996. Os limites originais do bioma Mata Atlântica na região Nordeste do Brasil. Rio de Janeiro: Fundação Brasileira para Conservação da Natureza, Forman, R.T.T. 86 p.

COUTINHO, LM., 2006. O conceito de bioma. Acta Botanica Brasilica, vol. 20, no. 1, p. 1-11. 
DECAËNS, T., LAVELLE, P., JIMÉNEZ, JJ., ESCOBAR, G. and RIPPSTEIN, G., 1994. Impact of land management on soil macrofrauna in the Oriental Llanos of Colombia. European Journal of Soil Biology, vol. 30, no. 4, p. 157-168.

DECAËNS, T., MARIANI, L., BETANCOURT, N. and JIMÉNEZ, JJ., 2003. Seed dispersion by surface casting activities of earthworms in Colombian grasslands. Acta Oecologica, vol. 24, no. 4, p. $175-185$.

DINDAL, DL., 1990. Soil biology guide. New York: Wiley. $1348 \mathrm{p}$.

DOBLAS-MIRANDA, E., SÁNCHEZ-PIÑERO, F. and GONZÁLEZMEGÍAS, A., 2007. Soil macroinvertebrate fauna of a Mediterranean arid system: Composition and temporal changes in the assemblage. Soil Biology \& Biochemistry, vol. 39, no. 8, p. 1916-1925.

EGGLETON, P., BIGNELL, DE., SANDS, WA., MAWDSLEY, NA., LAWTON, JH., WOOD, TG. and BIGNELL, NC., 1996. The diversity, abundance, and biomass of termites under differing levels of disturbance in the Mbalmayo Forest Reserve, southern Cameroon. Philosophical Transactions of the Royal Society of London, Series B, vol. 351, p. 51-68.

ETTEMA, CH., COLEMAN, DC., VELLIDIS, G., LOWRANCE, R. and RATHBUN, SL., 1998. Spatiotemporal distribution of bacterivorous nematodes and soil resources in a restored riparian wetland. Ecology, vol. 79, no. 8, p. 2721-2734.

HARADA, AY. and BANDEIRA, AG., 1994. Estratificação e densidade de invertebrados em solo arenoso sob floresta primária e plantios arbóreos na Amazônia Central durante a estação seca. Acta Amazonica, vol. 24, no. 1-2, p. 103-118.

HERNÁNDEZ, MIM., 2007. Besouros escarabeíneos (Coleoptera: Scarabaeidae) da Caatinga paraibana, Brasil. Oecologia Brasiliensis, vol. 11 , no. 3, p. 356-364.

JIMÉNEZ, JJ., ROSSI JP. and LAVELLE, P., 2001. Spatial distribution of earthworms in acid-soil savannas of the eastern plains of Colombia. Applied Soil Ecology, vol. 17, no. 3, p. 267-278.

JOUQUET, P., DAUBER, J., LAGERLÖF, J., LAVELLE, P. and LEPAGE, M., 2006. Soil invertebrates as ecosystem engineers: intended and accidental effects on soil and feedback loops. Applied Soil Ecology, vol. 32, no. 2, p. 153-164.

LAVELLE, P., 1983. The soil fauna of tropical savannas. I. The community structure. In BOURLIÈRE, F. (ed.). Tropical Savannas. Amsterdam: Elsevier. p. 477-484.

-, 1997. Faunal activities and soil processes: adaptive strategies that determine ecosystem function. Advances in Ecological Research, vol. 27, no. 27, p. 132.

LAVELLE, P., CHAUVEL, A. and FRAGOSO, C., 1995. Faunal activity in acid soils. In DATE, RA. (ed.). Plant Soil Interactions at Low pH. Dordrecht: Kluwer Academic Publishers. p. 201-211.

LAVELlE, P., DANGERFIELD, M., FRAGOSO, C., ESCHENBRENNER, V., LÓPEZ-HERNÁNDEZ, D., PASHANASI, B. and BRUSSAARD, L., 1994. The relationship between soil macrofauna and tropical soil fertility. In WOOMER, PL. and SWIFT, MJ., eds. The Biological Management of Tropical Soil Fertility. Chichester: John Wiley. p. 137-169.

LEAL, IR., SILVA, JMC., TABARELLI, M. and LACHER, TE., 2005. Changing the course of biodiversity conservation in the
Caatinga of Northeastern Brazil. Conservation Biology, vol. 19, no. 3, p. 701-706.

LIMA, JT. and COSTA-LEONARDO, AM., 2007. Recursos alimentares explorados pelos cupins (Insecta: Isoptera). Biota Neotropica, vol. 7, no. 2, p. 243-250.

MOONEY, HA., 1981. Primary production in Mediterranean-climate regions. In DI CASTRI, F., GOODALL, DW. and SPECHT, RL. (eds). Mediterranean-Type Shrublands Ecosystem 11. Elsevier Scientific Publications, Amsterdam. p. 249-255.

Paraíba. Governo do Estado, 1985. Atlas geográfico do Estado da Paraíba. João Pessoa: Grafset. 100 p.

PETERSEN, H. and LUXTON, M., 1982. A comparative analysis of soil fauna populations and their role in decomposition processes. Oikos, vol. 39, no. 3, p. 287-388.

PRADO, D., 2003. As caatingas da América do Sul. In LEAL, IR., TABARELLI, M. and SILVA, JMC. (ed.). Ecologia e conservação da Caatinga. Recife: Universidade Federal de Pernambuco. p. 3-73.

ROSSI, JP., LAVELLE, P. and ALBRECHT, A., 1997. Relationships between spatial pattern of the endogeic earthworm Polypheretima elongata and soil heterogeneity. Soil Biology \& Biochemistry, vol. 29 , no. 3-4, p. 485-488.

SANTOS, AM. and TABARELLI, M., 2002. Distance from roads and cities as a predictor of habitat loss and fragmentation in the caatinga vegetation of Brazil. Brazilian Journal of Biology, vol. 62 , no. 4B, p. 897-905.

SILVA, EG. and BANDEIRA, AG., 1999. Abundância e distribuição de cupins (Insecta: Isoptera) em solo de Mata Atlântica, João Pessoa, Paraíba, Brasil. Revista Nordestina de Biologia, vol. 13, no. 1-2, p. 13-36.

SILVA, RF., AQUINO, AM., MERCANTE, FM. and GUIMARÃES, MF., 2006. Macrofauna invertebrada do solo sob diferentes sistemas de produção em Latossolo da Região do Cerrado. Pesquisa Agropecuária Brasileira, vol. 41, no. 4, p. 697-704.

SOUTO, PC., SOUTO, JS., MIRANDA, JRP., SANTOS, RV. and ALVES, AR., 2008. Comunidade microbiana e mesofauna edáficas em solo sob caatinga no semi-árido da Paraíba. Revista Brasileira de Ciência do Solo, vol. 32, no. 1, p. 151-160.

StatSoft, 1995. STATISTIC 5.0. Oklahoma: Inc. Tulsa.

STORK, NE. and EGGLETON, P., 1992. Invertebrates as determinants and indicators of soil quality. American Journal of Alternative Agriculture, vol. 7, no. 1, p. 38-47.

SWIFT, MJ., HEAL, OW. and ANDERSON, JM., 1979. Decomposition in Terrestrial Ecosystems. Oxford: Blackwell. $372 \mathrm{p}$.

VALENTI, MW., CIANCIARUSO, MV. and BATALHA, MA., 2008. Seasonality of litterfall and leaf decomposition in a cerrado site. Brazilian Journal of Biology, vol. 68, no. 3, p. 459-465.

VASCONCELLOS, A., ANDREAZZE, R., ALMEIDA, AM., ARAÚJO, HFP., OLIVEIRA, ES. and OLIVEIRA, U., 2010a. Seasonality of Insects in the Semi-Arid Caatinga of Northeastern Brazil. Revista Brasileira de Entomologia, vol. 54, no. 3, p. 471-476.

VASCONCELLOS, A., BANDEIRA AG., MOURA FMS., ARAÚJO, VFP. and CONSTANTINO, R., 2010b. Termite assemblages in 
three habitats under different disturbance regimes in the semi-arid Caatinga of NE Brazil. Journal of Arid Environments, vol. 74, no. 2, p. 298-302.

VELLOSO, AL., SAMPAIO, EVSB. and PAREYN, FGC., 2002. Ecorregiões propostas para o bioma Caatinga. Recife. $76 \mathrm{p}$.

WALLWORK, JA., 1970. Ecology of soil animals. England: McGraw - Hill Publishing Company. 283 p.
WHITFORD, WG., 1996. The importance of the biodiversity of soil biota in arid ecosystems. Biodiversity and Conservation, vol. 5, no. 2, p. 185-195.

WOOD, TG., JOHNSON, RA., BACCHUS, S., SHITTU, MO. and ANDERSON, JM., 1982. Abundance and distribution of termites (Isoptera) in a riparian forest in the southern Guinea savanna vegetation zone of Nigeria. Biotropica, vol. 14, no. 1, p. 25-39. 